Shvedova Hanna,

$\mathrm{PhD}$ (Law Sciences), Associate Professor, Kyiv National University of Trade and Economics, 19, Kyoto str., Kyiv, 02156, Ukraine

ORCID: 0000-0002-0652-8493

Researcher ID: G-5998-2019

\title{
CORRUPTION AND HUMAN TRAFFICKING - A THREAT TO THE ECONOMIC SECURITY OF THE STATE
}

The most effective means of corruption's prevention as a threatening phenomenon for the development of any democratic state were identified. The phenomenon of corruption as a factor in dissemination of human trafficking was researched. It's includes civil-control institutes, the upbringing of social culture towards the formation of an ideology of anti-corruption behavior in society based on the principles of the cultural concept of counteraction to crime.

Key words: corruption, human trafficking, prevention, social culture.

Шведова Ганна. Корупція і торгівля людьми - загроза економічній безпеці держави.

Визначено найефективніший засіб запобігання корупиї як загрозливе явище для розвитку будь-якої демократичної держави. Досліджено явище корупиіі як чинник розповсюдження торгівлі людьми. Він включає інститути цивільного контролю, виховання сочіальної культури до формування ідеології антикорупційної поведінки в суспільстві на основі принщипів культурної концепиії протидії злочинності.

Ключові слова: корупиія, торгівля людьми, запобігання, соиіальна культура.

Relevance of research topic. Human trafficking is a crime that violates the rights to freedom, to human honor and dignity. Every year about 4 million people become victims of human trafficking. Only in the Western Europe about 500 thousand women are being sold each year. According to unofficial data in a sphere of sex industry of the recipient countries, from 100 to 600 thousand Ukrainian women are exploited. The substantial spreading of this crime in Ukraine had prompted national legislators to take decisive actions against human trafficking.

The prevalence of human trafficking, the imperfection of criminal legislation on liability for it, are predetermine the relevance of the research of this disgraceful phenomenon, which was appeared in ancient times and till nowadays is actual, being 
modified in more modern forms. The introduction of international agreements, which were directed to counteraction of human trafficking, made it possible to conclude that human trafficking was first internationally condemned only at the beginning of the 19th century. Since then, more than 20 international agreements have been concluded (1, p. 302).

Despite the growing efforts to investigate criminal proceedings, prosecute and condemn people which are involved in human trafficking, the most convicted traffickers in Ukraine are sentenced to imprisonment by the high level of corruption in the country.

Several significant factors, such as Russian aggression, corruption and ineffective measures are prevent the full implementation of laws (2). Consequently, the problem of counteraction of human trafficking is multidimensional. The reducing corruption in state agencies, where the victims of trafficking are taken out, and in other areas, is of paramount importance. Such acts will contribute to reducing the level of criminality concerning the illegal exploitation of vulnerable populations, and will make the process of illegal migration more manageable in the world and in individual countries. So, corruption and human trafficking is a serious treat to the economic security of the state, which is too relevant in Ukraine and in a world at all.

\section{Aim of paper.}

The purpose of the work is to analyze the phenomenon of corruption as a factor of the dissemination of human trafficking, to reveal it's interconnection and interdependence, and to find out the most effective means of corruption's prevention as a threatening phenomenon for the development of any democratic state.

Analysis of latest research and publication. Different scientists analyzed criminological and criminal-legal aspects of prevention of corruption and human trafficking in their scientific works. They are: Yu. V. Baulin, V. V Golina, V. M. Kutc, A. A. Musica, A. M Orlean, V. M. Podgorodinsky, E. L. Streltsov, M. I. Havronyuk, S. D. Shapchenko and other scholars. However, the research of corruption as a factor in the dissemination of human trafficking did not founded it's detailed analysis in these works.

Exposition of main material of research. According to the report of the American State Department «Human trafficking 2017» Ukraine does not fully responsible to the minimum standards for the elimination of human trafficking. Such report consists information concerning our country about that. Ukraine does not apply all possible measures to put an end to human trafficking. Although marked, that Ukraine makes some progress in this sphere. In this regard, Ukraine during the last four years is on the second level in the ranking of countries in a sphere of the counteraction of human trafficking (the third level - is the lowest indicators in this sphere).

The significantly influence to this situation are extended such factors as Russian aggression, corruption and ineffective implementation of laws (3). For many countries, 
this problem is also actual. Public Advocate of the Freedom Network USA Martin Vandenberg works with victims of human trafficking in the United States noted such posts. Unlike the other criminal organizations, human traffickers often work independently, much smaller of the number of participants and therefore they are more difficult to detect. Sometimes these groups consist of family members and therefore very stable. Vandenberg also pay attention to fact, that human traffickers «fueled» by corruption and often the law enforcement authorities by themselves are contribute to organized crime in poor countries.

Victims do not inform about the trafficking cases, because they think that at the homeland law-enforcement bodies are corrupted. They are afraid of police and judges, who are related to criminals. "They are afraid to be simply detained by the police, for them it is more terrible than slavery. Human traffickers use this situation», - notes Vandenberg. The research of the problem of human trafficking proves, that it is necessary to pay more attention to problem of corruption in a state institutions of those countries from where the victims of human trafficking are taken out. Because usually the main accessories of crimes could become law enforcement, customs officers and even diplomats who use their immunity.

Also it was proved, that illegal human trafficking, which is promoted by corruption, is a threat to the national security of the states. Corruption and trade are the sources of instability in many countries around the world. In particular, in Syria and Iraq, in some African countries life becomes more difficult. However the impact of illegal human trafficking and corruption are feel all members of society. Corruption promotes the dissemination of illegal trade both in the real world and in a virtual world, making goods and services of the illegal economy more widely available.

It is proved, that all this illegal business, which is promoted by corrupt officials, exists today for transportation or human trafficking. People are selling the latest goods for pay to smugglers who can deliver their families to a safe place. Often they are become victims of human traffickers and often forced to work in slavery in Europe. Moreover, the massive movement of migrants in desperation to neighboring countries and Europe has created serious political and economic crises in destination countries, that were not ready to receive millions of displaced persons.

The analysis of the overview about the human trafficking situation in the world shows, that solving this problem is requires the removal of existing preconditions of it's emergence and spreading. First of all, we are talking about corruption as a catalyst for the human trafficking. In national practice for the tangible results in the process of counteracting corruption, firstly, it is necessary to change the existing approaches that have emerged in the public consciousness of the perception of corruption as a habitual phenomenon.

Introduction the public education in all spheres of state activity will promote the formation of the proper level of social culture. It will also raise people in the direction of adherence to the norms of law. Ideology, based on the upbringing of a sense of 
public duty, the desire to be useful to society and the awareness of the value of personal material welfare as a derivative of the public welfare, will provide an opportunity to form the necessary level of social culture of society. Often an obstacle to implementation the anti-corruption strategies is a factor of mentality in Ukrainian society, in particular, the indifference to bureaucratic abuses, the justification of corruption behavior by the circumstances of life, which is primarily due to the tendency of Ukrainians to individualism (4).

In the social political sense corruption has long been perceived as a criterion for maturity, for the activity of the modern public society. Public control can be realized through the parliaments, bodies of self-government, mass media, public organizations. With it's help control could set over the activity of state administrative structures and the credibility of trust could increase as for the government and parliament.

The level of interest of the political elite in cooperation with public society organizations is negligible. Although the role of public organizations in anti-corruption activity is admitted.

The development of democratic countries is always accompanied by the strengthening of the institutions of public control over the activities of the public service. This fact helps to increase the trust for the government and parliament. Despite the particular flaws (excessive emotionality of public relations), it is believed that public institutions could be the main chain in the process of prevention of corruption in democratic organizations. There are several reasons. Firstly, the involvement of the public sector into the corruption relations. Also public sector includes more kinds of legal relations than the state sphere. It has more powerful potential in counteraction of corruption. But, on the other hand, it is necessary to unite of state and public forces in this process. The last have to create appropriate normative practice for the development of the public initiatives.

Areas of counteraction of corruption and human trafficking are most in need of involvement of public society institutions. Consequently, to eradicate corruption so quickly will be too difficult task. Because it laid the «strong roots» in all spheres of life in Ukrainian society (5).

The nature of the phenomenon of corruption in a modern society of Ukraine, which determines the existence of a special mechanism for corruption relations, the nature of corruption criminality and forms the crisis type corruption in the country. Such type of it is extending the crisis in all other spheres of public life and requiring the special advanced anti-corruption strategies.

Corruption is considered to be a system of negative attitudes, social disease in society, and basically has a psychological setting to use the public service for the corrupt purposes. Such change of mentality in the direction of improving the social, including political culture of all participants of corrupt relations, should become the effective direction of anti-corruption activity. The corruption of «type of crisis» generates the citizens, who have not the proper level of social culture. The 
counteraction of such type of corruption needs the corresponding technology with the involvement of international experience.

It is important to know, that it is impossible to solve the problem of corruption only by the criminal legal repression. Therefore, to use the new progressive strategies with a variety of social technologies can be productive way. Thereby the institute of prevention of the "conflict of interests» in the public service requires the special attention. The legislation of those countries, which have achieved the success in the anti-corruption activity, already contains the norms for the regulation of such institute. It can be done by the establishing the corresponding control, prohibited, restricted means, which have to play an important role in counteraction of corruption in general. The application of such experience will create a good practice in this sphere for other states.

There are special bodies in some countries, which control the situation to eliminate such conflict. The Nolan's Committee regulates such «conflict of interests» in Great Britain. Besides, a contender for the ministerial post has to submit a list of all his financial interests, but not just the income declaration. Than, all information has to be analyzed in details. After that a person can be offered to change the location of his assets or to cease the cooperation with some companies. In the Netherlands there are internal security services in all organizations. They detect the blunders of officials. In Germany the official has to obtain the prior permission from the highest official authority for extra work. Besides the new job after the termination of official duties will be prohibited if it harms the interests of the service (6).

Also it is worth paying attention to the principle of transparency in the activity of public officials, because having the full information about it the general public can actively participate in this sphere. Therefore it will facilitate the ruling of democracy in the country. It is proposed to minimize the number of licenses, permits, to simplify the procedure of its receiving. At once it should be reduced the registration of a new private enterprise to a single action for minimizing the degree of dependence in these procedures from the officials. Besides, it should be embed the modern information technologies by introducing the electronic forms of documents, automated control systems for receive and review the documents. It will contribute to the practice of correct realization the public services and will minimize the personal contacts of officials with citizens and will increase the transparency of such processes.

It is known that corruption is a destructive factor in the mechanism of state power. It is increases the degradation processes in the country. To stop it is necessary to stabilize the political situation. One of the way of stabilization is to choose the formation of public opinion in the corresponding direction.

Conclusion. Fact is, that human trafficking is a crime that violates the rights to freedom, to human honor and dignity, that enshrined and guaranteed by the Constitution of Ukraine. Despite the growing efforts to investigate criminal proceedings, prosecute and condemn people which are involved in human trafficking, 
the most convicted traffickers in Ukraine are sentenced to imprisonment by the high level of corruption in the country. The analysis of the problem of human trafficking give us such conclusion, that it is necessary to pay more attention to corruption in state institutions of those countries from where the victims of human trafficking are taken out. Because usually the main accessories of crimes could become law enforcement, customs officers and even diplomats who use their immunity.

Human traffickers «fueled» by corruption and often the law enforcement authorities by themselves are contribute to organized crime in poor countries. It is necessary to change the existing approaches that have emerged in the public consciousness of the perception of corruption as a habitual phenomenon. It will help to get real results in a counteraction of corruption. Indeed, according to some researchers in countries where public organizations are actively involved into the implementation of community programs, corruption is less widespread. Areas of counteraction of corruption and human trafficking are most in need of involvement of public society institution.

\section{REFERENCES}

1. Pidhorodynskyi V.M. Criminal and legal deviation against honour and dignity on different levels. Scientific Papers Odessa National Law Academy. Book 16. Odessa, Ukraine, 2015. P. 301-308.

2. The official site of web-based media VOA (2018), «Ukraine: US State Department report on human trafficking». Retrieved from: https://ukrainian.voanews. com/a/us-ukraine-human-trafficking/3398912.html

3. The official site of The Ministry of Social Policy of Ukraine (2018), «Ukraine has made a significant progress in combating against human trafficking in the last years and has advanced on the higher level in country ranking of US State Department». Retrieved from: http://www.msp.gov.ua/news/13524.html?PrintVersion. (In Ukrainian)

4. The official site of web-based media NATO Review (2017), «New security challenge: the growth of illicit trade and corruption». Retrieved from: https://www.nato.int/ docu/review/2017/Also-in-2017/new-security-challenge-the-growth-of-illicit-tradeand-corruption-wolrd/UK/index.htm

5. Razumkov Centre (2012), «Political corruption in Ukraine: subjects, manifestations, problems of counteraction». Retrieved from: http://razumkov.org.ua/ ukr/files/category_journal/NSD111_ukr_1.pdf.

6. The official site of web-based media VOA (2019), «Why human trafficking is still a serious problem and how to deal with it?». Retrieved from: https://ukrainian. voanews.com/a/human-trafficking-11-04-2011-133248733/245490.html. 